УАК 657.375.6(477)

JEL Code M41

\section{СИСТЕМА ЗВІТНО-ОБЛІКОВОГО ЗАБЕЗПЕЧЕННЯ УПРАВЛІННЯ: МИНУЛЕ Й МАЙБУТН ${ }^{\odot}$}

\author{
B.M. ЖУК, \\ доктор економічних наук, професор, \\ академік НААН, \\ головний науковий співробітник, \\ Національний науковий центр \\ "Інститут аграрної економіки», \\ (м. Kü̈в) \\ К.П. МЕЛЬНИК, \\ кандидат економічних наук, доцент, \\ Східноєвропейський університет \\ імені Лесі Украӥнки, \\ (м. Луцьк)
}

Дослідження засвідчили відсутність натепер в Україні изілісної і комплексної системи звітно-інформаційного забезпечення управління. Скорочення форм фінансової і статистичної звітності аграрних підприємств мотивовано не лише євроінтеграційними процесами, $a$ i реформуванням галузевої системи управління. В краӥні наявна проблема прийняття політичних $i$ управлінських рішень без належного обліково-інформаційного забезпечення. Встановлено, щцо імплементування у вітчизняній простір світового тренду інтегрованої звітності, наявні в Україні процеси децентралізаиії та розвитку ринку бухгалтерського аутсорсингу формують базові основи для відновлення $і$ розбудови нової звітної системи. Встановлено, щяо вимоги GRI, IIRF, Директиви 2013-34GI до показників інтегрованої звітності багато в чому повторюють вимоги до заповнення форм річного звіту сільськогосподарських підприємств радянського періоду. Зроблено висновок, щчо для посилення ефективності інтегрованої звітності Украӥні доцільно використати методологічні ци методичні напрачювання з бухгалтерського обліку $i$ звітності радянського періоду. Запропоновано приничипи та конщептуальні положення розбудови системи обліковоінформачійного забезпечення управління в аграрному секторі економіки з врахуванням світових тендениій та національного історичного досвіду.

Ключові слова: бухгалтерська звітність, статистика сільського господарства й сільських територій, система інформаційного забезпечення управління, концепція, інтегрована звітність.

Рис. 3. Табл. 3. Літ. 12.

\title{
SYSTEM OF REPORTING MANAGEMENT SUPPORT: THE PAST AND THE FUTURE
}

Valeryi ZHUK, Doctor of Economic Sciences, Professor, Academician of NAAS, Leading Researcher, National scientific centre "Institute of agrarian economics" (Kyiv)

Kateryna MELNYK, Candidate of Economic Sciences, Associate Professor, Lesya Ukrainka Eastern European National University

(Lutsk)

Studies have shown the absence at the moment in Ukraine of a coherent and integrated system of reporting and information support of management. The reduction of forms of financial and statistical reporting of agrarian enterprises is motivated not only by European integration processes but also by the reformation of the sectoral management system. The country has a problem of making political and 
http://efm.vsau.org/

managerial decisions without proper accounting and information support. It has been established that the implementation of the global trend of integrated reporting in the domestic space, the existing decentralization processes and the development of the accounting outsourcing market in Ukraine form the basic basis for the restoration and development of a new reporting system. It has been established that the requirements of GRI, IIRF, Directive 2013-34GI to the indicators of integrated reporting in many respects repeat requirements for filling in the forms of the annual report of agricultural enterprises of the Soviet period. It is concluded that in order to increase the efficiency of integrated reporting, it is advisable to use methodological and methodical developments from the accounting and reporting of the Soviet period. Principles and conceptual provisions of the development of the accounting and information support system for the agricultural sector of the economy taking into account world trends and national historical experience are proposed.

Keywords: accounting reports, statistics of agriculture and rural areas, management information support system, concept, integrated reporting.

Pict. 3. Tabl. 3. Lit. 12.

\title{
СИСТЕМА ОТЧЕТНО-УЧЕТНОГО ОБЕСПЕЧЕНИЯ УПРАВЛЕНИЯ: ПРОШЛОЕ И БУДУЩЕЕ
}

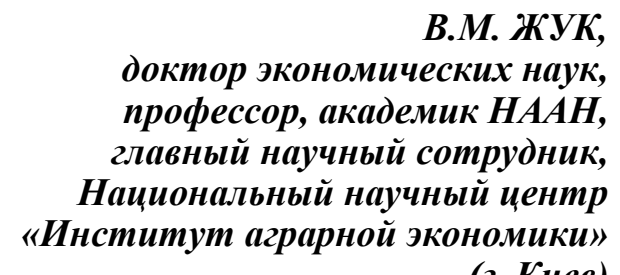

(2. Киев)

К.П. МЕЛЬНИК, кандидат экономических наук, доцент, Восточноевропейский университет имени Леси Украинки (2. Луцк)

\begin{abstract}
Исследования показали отсутствие на данный момент в Украине целостной и комплексной системы отчетно-информационного обеспечения управления. Сокращение форм финансовой и статистической отчетности аграрных предприятий мотивировано не только евроинтеграџионными процессами, а и реформированием отраслевой системы управления. В стране имеется проблема принятия политических и управленческих решений без надлежащего учетно-информационного обеспечения. Установлено, что имплементирования в отечественной пространство мирового тренда интегрированной отчетности, имеющиеся в Украине процессы децентрализации и развития рынка бухгалтерского аутсорсинга формируют базовые основы для развития новой отчетной системы. Установлено, что требования GRI, IIRF Директивы 201334GI $\kappa$ показателям интегрированной отчетности во многом повторяют требования к заполнению форм годового отчета сельскохозяйственных предприятий советского периода. Сделан вывод, что для усиления эффективности интегрированной отчетности Украинь целесообразно использовать методологические и методические наработки по бухгалтерскому учету и отчетности советского периода. Предложены принципы и концептуальные положения развития системы учетно-информационного обеспечения управления в аграрном секторе экономики с учетом мировых тенденций и национального исторического опыта.

Ключевые слова: бухгалтерская отчетность, статистика сельского хозяйства и сельских территорий, система информационного обеспечения управления, концепция, интегрированная отчетность.

Рис. 3. Табл. 3. Лит. 12.

Постановка проблеми. Бездумне виконання процедур євроінтеграції фінансової i статистичної звітності в Україні, по факту, створило проблеми інформаційного забезпечення управління. В інформаційному хаосі перебувають не тільки загальнодержавні і галузеві органи управління, але і підприємства. I справа не стільки у скороченні звітних форм під приводом уникнення дублювання показників чи орієнтація методології із суцільного обліку на спостереження, а більше у руйнуванні попередньої системи та неспроможності (фінансовій i організаційній) натепер сформувати систему подібну розвинутим країнам. Відомо, що значне місце
\end{abstract}


в останній займає не стільки загальнодержавна звітність, скільки відомча статистична, адмінспостереження місцевих органів влади, наукові і експертні дослідження, що об'єднуються в одну консолідовану систему. Останніми роками до цієї системи додається і вагомий сегмент інтегрованої звітності. 32017 р. в СС набула обов'язкового характеру Директива 2013-34GI щодо надання компаніями 3 персоналом понад 500 осіб обов'язкової звітності з екологічних, соціальних аспектів діяльності, дотриманню прав людини, особливостей корпоративного управління, боротьби 3 корупцією та хабарництвом, перспектив інноваційного розвитку та іншої цікавої для громадськості інформації, як фінансового, так і нефінансового характеру. Методологічну й методичну основу такої звітності формують стандарти Міжнародної ради з інтегрованої звітності та стандарти Міжнародної організації з розвитку звітності сталого розвитку. Окрім цього, особливе місце у системі звітності розвинутих країн займає сегмент інституту аудиторської діяльності. Останній не тільки забезпечує довіру до інтегрованої звітності, але і допомагає, і популяризує іiі складання й роз'яснення.

Значна частина вітчизняних вчених, і ми поділяємо цю думку, вважає, що імплементування Мінфіном України підходів і принципів інтегрованої звітності (включаючи запровадження з 2019 року «Звіту про управління») активізує дискусію навколо проблем вітчизняної системи обліковоінформаційного забезпечення управління. Відтак актуальними стають дослідження на розбудову сучасної системи звітності, з врахуванням світових тенденцій, національних інтересів та можливостей IT.

Метою статті є обгрунтування концептуальних положень формування й розвитку в Україні системи обліково-інформаційного забезпечення управління з урахуванням сучасних світових тенденцій, національних потреб та можливостей ІТ-технологій.

Аналіз останніх досліджень і публікацій. Значний внесок до наукового забезпечення розвитку бухгалтерської звітності, формування комплексної системи обліково-інформаційного супроводу процесів управління проводить професорсько-викладацький склад Вінницького національного аграрного університету. Зокрема, Л.В. Гуцаленко та Е.О. Довгаль обгрунтували принципи побудови обліково-інформаційної системи забезпечення управління сільськогосподарським підприємством [1]. Н.Л. Правдюк у своєму дослідженні торкається організаційно-методичних питань підготовки звітності щодо спільної діяльності без створення юридичної особи [2]. Удосконаленню фінансової звітності фермерських господарств в частині державної підтримки присвячена робота Н.Г. Здирко [3].

Серед інших науковців, варто відмітити К.В. Безверхого, об'єктом досліджень якого є методичні засади формування інтегрованої звітності підприємства [4]. С.Ф. Легенчук та Н.М. Батіщева вивчають галузеві особливості представлення фінансової інформації у фінансовій звітності футбольного клубу [5].

Піднятим у даній статті питанням приділяється увага і у академічній науковій школі бухгалтерського обліку [6, 7].

Методологія та методи дослідження. Для постановки гіпотези дослідження та ії доведення використано методи і прийоми наукового пізнання. Метод індукції, дедукції та абстрагування використано для вивчення минулих здобутків вітчизняної наукової школи з бухгалтерського обліку щодо удосконалення інформаційного забезпечення управління народним господарством та прогнозування розвитку розширеної (інтегрованої) звітності в Україні. Проведено системний аналіз побудови та організації інтегрованої звітності в Україні та світі. Завдяки здійсненню моделювання із застосуванням аксіоматичного й гіпотетичного методу запропоновано принципи та концептуальні положення розбудови системи обліково-інформаційного забезпечення управління в аграрному секторі економіки.

Виклад основного матеріалу дослідження. Натепер офіційна система інформаційного забезпечення управління аграрною галуззю має трирівневу побудову. Державна служба статистики України вибудовує їі на базі фінансової та статистичної звітності й спостережень. Обласні і районні державні адміністрації ще, поки що по інерції, збирають адміністративну звітність. Підприємства мають можливість доповнювати офіційну звітність даними управлінського обліку. Поза системою були і залишаються експертні і наукові дослідження. I, якщо перші ще якось фінансуються міжнародними грантовими проектами та агрохолдингами, то наукові, де бракне фінансування, зведені нанівець. Неінтегрованою до системи залишається звітність Держгеокадастру та Державної фіскальної служби України.

Загалом, динаміка кількості форм статистичних спостережень має стійку негативну тенденцію (рис. 1). 


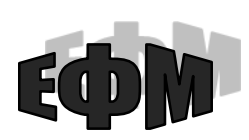

http://efm.vsau.org/

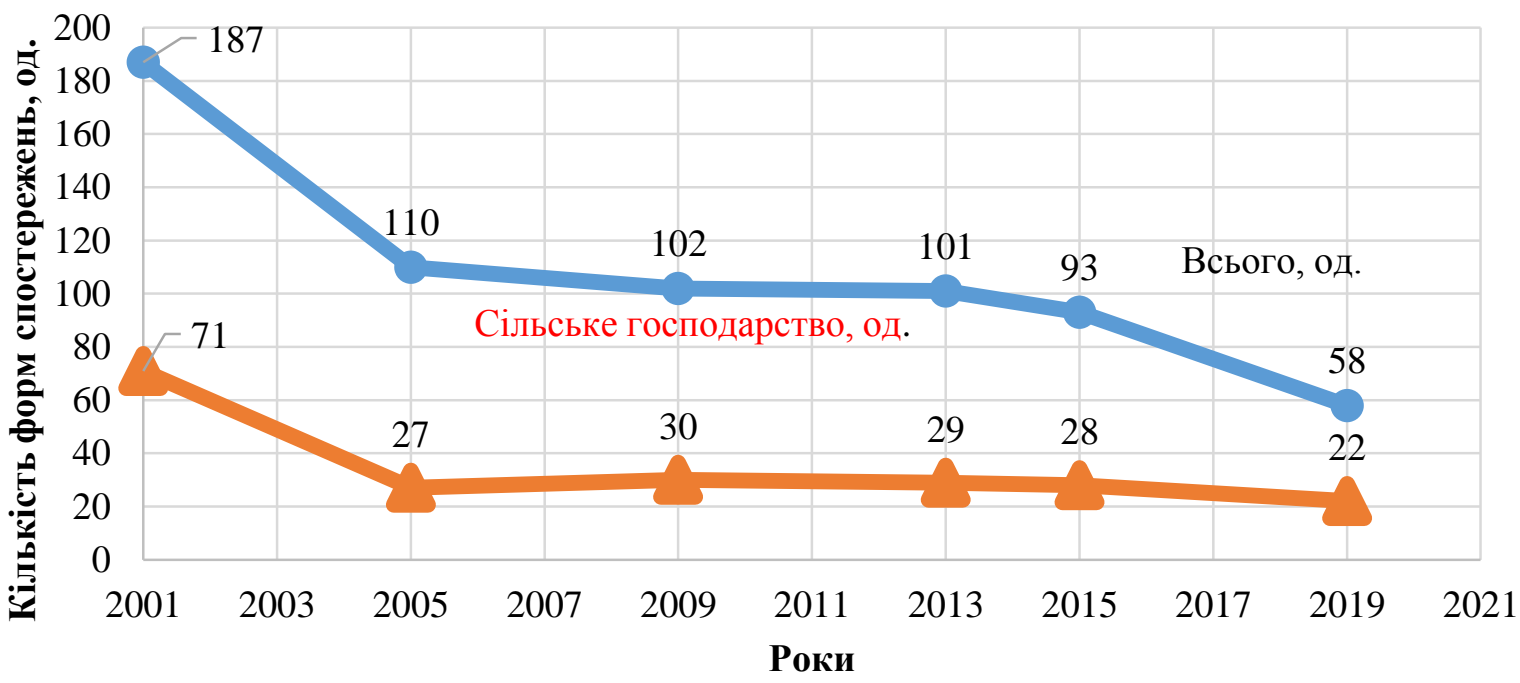

Рис. 1. Динаміка кількості форм статистичних спостережень в Україні

Джерело: сформовано автором на основі даних офіиійного веб-сайту Державної служби статистики Украӥни: http://www.ukrstat.gov.ua/

У структурі форм, що залишаються, 71\% займає сегмент економічної статистики, 25\% демографічної та соціальної і 4\% - навколишнього середовища. Серед інших, сільське господарство має пріоритетність по застосуванню форм спостережень - 38\% (рис. 2). і, окрім своїх, звітує і по інших формах, наприклад, «капітальні інвестиції і основні засоби».

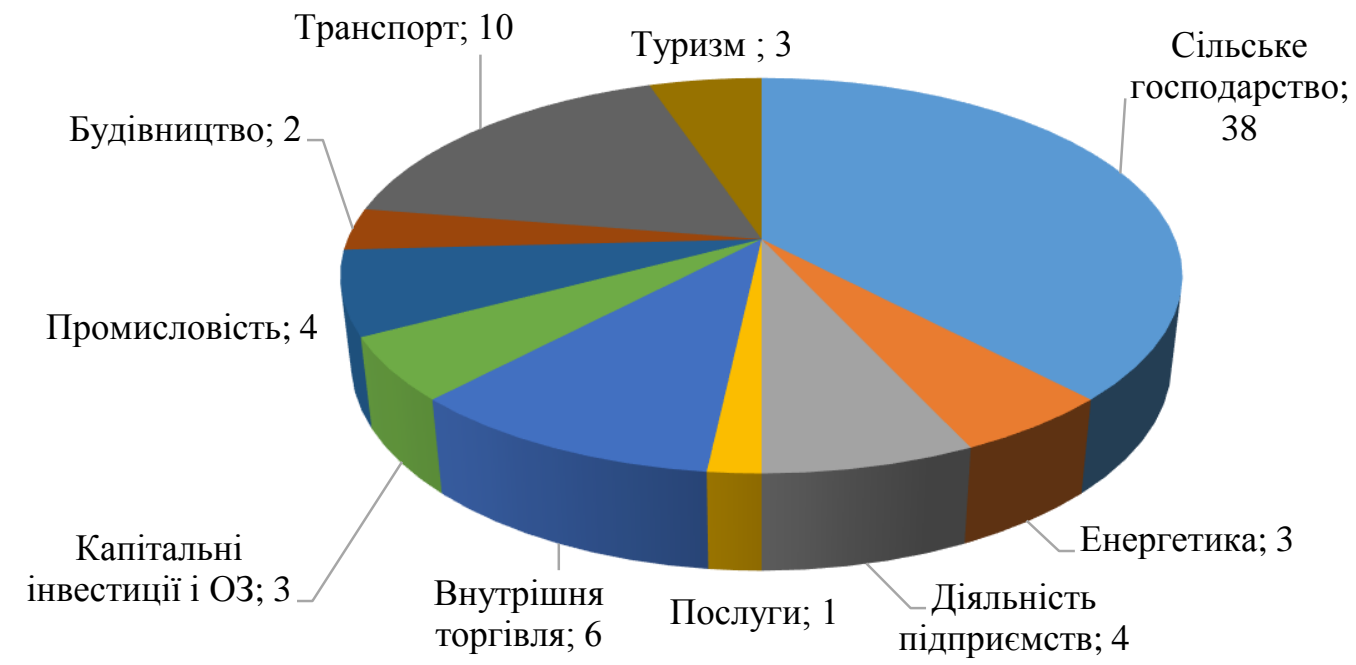

Puc. 2. Аграрний пріоритет статистичних спостережень, \%

Джерело: сформовано автором на основі даних офіиійного веб-сайту Державної служби статистики України: http://www.ukrstat.gov.ual

Незважаючи на певну пріоритетність і наявність хоч якоїсь, у порівнянні з іншими галузями вітчизняної економіки, системи інформаційного забезпечення управління, сільське господарство України поступово втрачає керованість на галузевих та загальнодержавному рівнях.

Не секрет, що однією з причин втрати аграрним сегментом економіки спеціальних режимів оподаткування (ФСП і ПДВ) стала обмежена і недостовірна звітність по фінансових результатах господарювання. Необгрунтовано завищену рентабельність галузі не було можливості пояснити звітними даними по стану необоротних активів, амортизаційної політики, стану оплати праці, трансфертного ціноутворення у вертикально-інтегрованому бізнесі та інших факторів, які вплинули на «звітну прибутковість». Неефективною в цьому сенсі виявилась і система податкової звітності, яка під «личиною спрощення» не сформувала інформації для запобігання негативним явищам агрохолдингізації галузі, тінізації ії економіки.

Варто зазначити, що до 2010 року Міністерство аграрної політики і продовольства України розуміло і всіляко намагалось зберегти систему інформаційного забезпечення галузевого управління. 
Варто зазначити, що до 2010 року Міністерство аграрної політики і продовольства України розуміло i всіляко намагалось зберегти систему інформаційного забезпечення галузевого управління. Продовжувала діяти Міністерська система адміністративної звітності через районні і обласні управління АПК держадміністрацій. Реформування Держкомстатом України статистичної звітності в обов'язковому порядку узгоджувалось з Міністерством. Мали місце постійні контакти з Мінфіном та Податковою службою України. При Міністерстві з 1992 року діяла науковометодологічна Рада 3 питань обліку і звітності, яка, окрім іншого, здійснювала нормативнометодичне забезпечення галузевої інформаційної системи. До Ради входили представники усіх сегментів звітності: Держкомстату, Мінфіну, податкової, обласних управлінь АПК.

Саме ця координація і узгодженість роботи дозволяла на початку 2000-х років на місці радянської системи звітності вибудовувати ії новий ринковий аналог. Початком цієї роботи стало запровадження річної звітності сільськогосподарських підприємств за формою 50 с.г. та формою 2 ферм. Згодом у 2004 році членами Ради (на базі академічної науки) було підготовлено Концепцію річної бухгалтерської звітності сільськогосподарських підприємств, проект форм відповідного Річного звіту та Інструкцію по його заповненню [8]. Певну інформаційну обмеженість пропонованої звітності (за критеріями оперативності і повноти) пропонувалось вирішувати через запровадження сегменту відомчої аграрної статистики. Науковцями у 2007 році були підготовлені Методичні рекомендації із облікового забезпечення відомчої (аграрної) статистики в тестових підприємствах [9]. Спільно з Податковою службою України Радою велась робота і по удосконаленню податкової звітності - запровадження єдиного земельного податку для малого і середнього підприємництва.

Проте з 2010 року, владним структурам загальнодержавного та галузевого рівнів об'єктивна інформація стала непотрібною. Комплексна і системна розбудова інформаційної системи управління зупинилась. Науково-методологічна Рада з обліку і звітності при Мінагрополітики 3 того часу не працює.

На сьогоднішній день залишки системи інформаційного забезпечення руйнують різного роду «грантоїдами» біля Мінагрополітики, Держкомстату та інших відомств України, які продукують сумнівні ініціативи. Наприклад: ініціативи щодо певного збору інформації по лінії Мінагрополітики з підприємств, які отримують державну підтримку. Причому акцент робиться на інформації більше з сегменту податкової звітності, оскільки натепер Мінагрополітики не може отримати такої інформації з ДФС. Там свої «грантові» реформи.

Отже, стара система і паростки нової системи інформаційного забезпечення управління в Україні натепер знищені. По факту існує політичне, в економічному сенсі «сліпе» управління галуззю.

Незважаючи на вищезазначені обставини, ми сподіваємось, що євроінтеграційна основа запровадження в Україні інтегрованої звітності та децентралізація, як каталізатор запитів на інформацію, сформує новий базис розбудови відповідної системи.

32017 р. до Закону України «Про бухгалтерський облік і фінансову звітність в Україні» звітність підприємств розширено новою формою «Звіт про управління» [10]. Передбачається його подання у складі фінансової звітності 3 обов'язковою аудиторською перевіркою та оприлюдненням. Для нормативно-правового забезпечення такої звітності внесено зміни до наступних документів: Господарський кодекс України; Кодекс України про адміністративні правопорушення; Закон України «Про бухгалтерський облік та фінансову звітність в Україні»; Закон України «Про аудит фінансової звітності та аудиторську діяльність»; Закон України «Про товариства з обмеженою та додатковою відповідальністю».

3 іншої сторони, процес формування об'єднаних територіальних громад (який небездоганний надмірним укрупненням) буде стимулювати запити до підприємництва на звітну інформацію. Місцеві органи влади вимушені будуть ідентифікувати та виводити з тіні усі економічні ресурси бізнесу для наповнення своїх бюджетів. Поступово сформуються і місцеві запити на інформацію соціального й екологічного характеру.

Наші дослідження перспектив інтегрованої звітності в аграрному секторі економіки України виявили ще один важливий важіль його розвитку. Це зацікавленість підприємництва в інформуванні громад про соціальну, екологічну, інноваційну сторону їх діяльності. Майже усі $з$ опитаних власників-керівників середніх підприємств бачать у такій звітності потребу та розуміють проблему недосконалості існуючих статистичних спостережень для галузевого управління. Становлення місцевих громад, їх органів самоврядування розуміння важливості системи інформаційного забезпечення управління територіями і галуззю зростає і у фермерів (табл. 1). 
Перспективи інтегрованої звітності зі сталого розвитку аграрним підприємств України*

\begin{tabular}{|c|c|c|c|c|}
\hline \multirow{2}{*}{$\begin{array}{c}\text { Види аграрних } \\
\text { підприємств }\end{array}$} & \multirow{2}{*}{$\begin{array}{c}\text { Середній земельний } \\
\text { банк, тис. га }\end{array}$} & \multirow{2}{*}{ Кількість, од. } & \multicolumn{2}{|c|}{$\begin{array}{c}\text { Оріснтовані на } \\
\text { інтегровану звітність, од. }\end{array}$} \\
\hline & & & 2019 p. & 2025 p. \\
\hline Великі (агрохолдинги) & Більше 15 & 150 & 150 & 150 \\
\hline Середні & Від 1,5 до 15 & 16200 & 1960 & 16200 \\
\hline Малі (фермерські) & До 1,5 & 38000 & 0 & 3700 \\
\hline
\end{tabular}

*Умови:

євроінтеграчія;

децентралізачія;

розвиток громадянського суспільства;

розбудова комплексної системи звітності.

Отже євроінтеграційний чинник, упорядкування процесу децентралізації, наростання соціальної й економічної відповідальності вітчизняних підприємств, створює нову основу для розбудови комплексної системи інформаційного забезпечення управління аграрною галуззю. Все це вимагає активізації відповідного науково-організаційного забезпечення.

Певним орієнтиром у цій роботі можуть бути напрями трансформації за Глобальною стратегією розвитку сільського господарства та сільської статистики ООН та ФАО, 2010 р. [11]. Концептуально стратегія передбачає два види звітності (статистична сільського господарства та статистична сільських територій) та три виміри (економічний, соціальний і екологічний) (табл. 2).

Основи глобальної стратегії розвитку сільської статистики ООН та ФАО 2010 р.

Таблиця 2

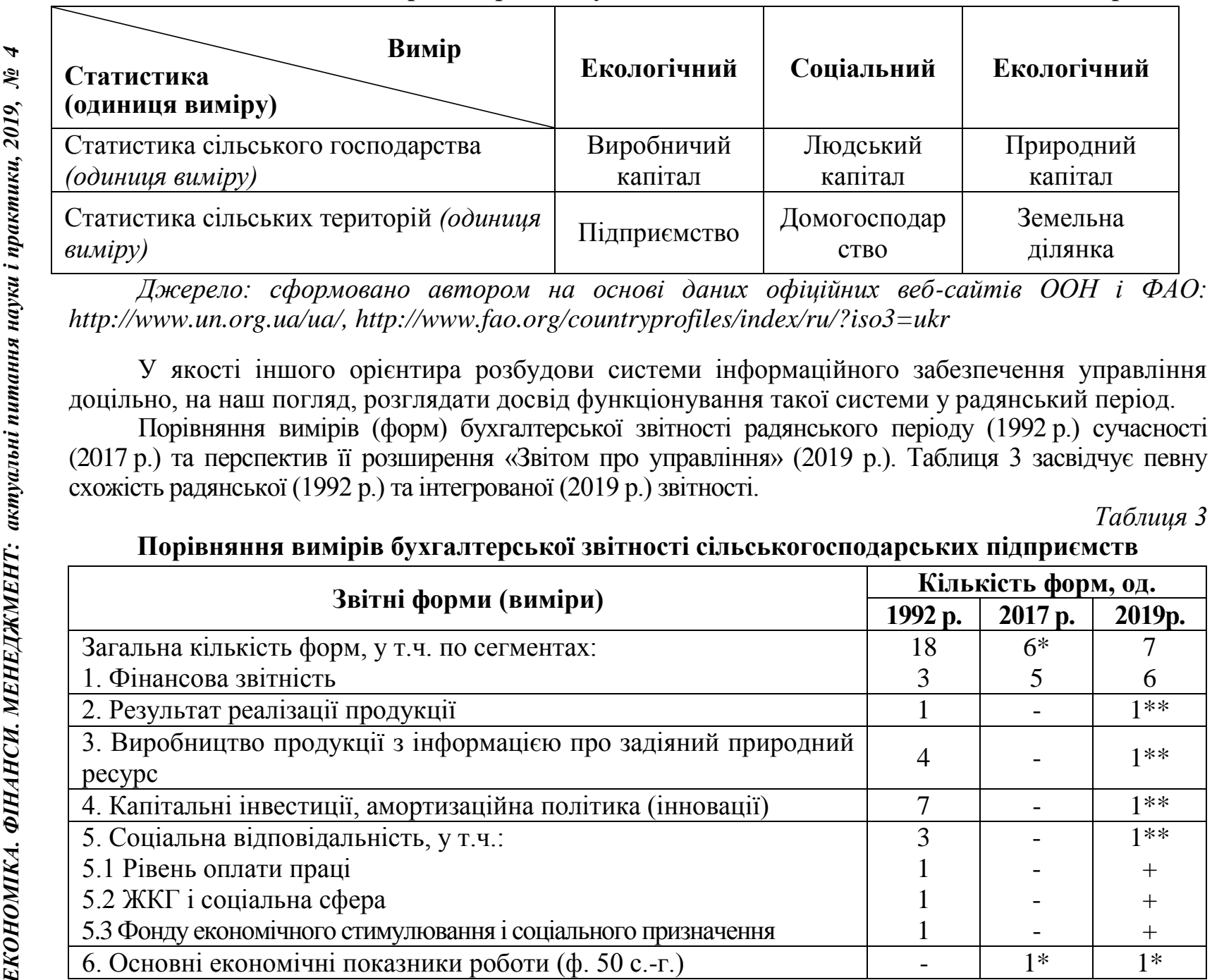


* форма 50 с.-г. у 2017 роиі зазнала значного скорочення показників під тиском західних «консультантів» на Держстат України

** відображення інформації у "Звіті про управління”

На початок 2019 року Мінфін України затвердив методичні рекомендації із складання «Звіту про управління〉 (№ 982 від 07.12.18) [12] з переліком наступних звітних вимірів: організаційна структура та опис діяльності; результати діяльності, ліквідність та зобов'язання; соціальні і екологічні аспекти; фінансові інвестиції; капітальні інвестиції (в т.ч. інноваційні), які по суті співставні зі звітністю радянського періоду. Рекомендації спонукають і до сучасних вимірів дослідження, якими $є$ перспективи розвитку підприємства, ризики, корпоративне управління тощо. Новою $є$ і форма подачі та оприлюднення, окрім таблиць - рисунки, графіки, діаграми, схеми, фото; оприлюднення на веб-сайтах підприємств.

Науково-організаційне забезпечення розбудови нової системи інформаційного забезпечення управління базується і на з'ясуванні переліку споживачів звітності. До державних інституцій загальнодержавного, галузевого та регіонального рівнів кредиторів, науковців, аналітиків додаються асоціації виробників, місцеві громади, громадянське суспільство. Тобто варто враховувати кількісну і якісну їх розбудову, що в сучасному світі асоціюється з концепцією зростання стейкхолдерів (рис. 3).

\begin{tabular}{|c|c|c|c|}
\hline \multirow{2}{*}{\multicolumn{4}{|c|}{ Ефективне інформаційне забезпечення управління/політики }} \\
\hline & & & \\
\hline \multicolumn{4}{|c|}{ Формування біхевіористичної основи важливості звітності } \\
\hline \multicolumn{4}{|c|}{$\widehat{\longleftarrow}$} \\
\hline \multicolumn{4}{|c|}{ Розвиток інститугу професійних бухгалтерів } \\
\hline \multicolumn{4}{|c|}{$\widehat{\longleftarrow}$} \\
\hline \multicolumn{4}{|c|}{ Система інформаційного забезпечення управління/сегменти } \\
\hline \multicolumn{4}{|c|}{$\widehat{\zeta}$} \\
\hline \multicolumn{4}{|c|}{ Система інформаційного забезпечення управління / сегменти: } \\
\hline \multicolumn{2}{|l|}{ Відомчі } & \multicolumn{2}{|c|}{ Регіональні/місцеві } \\
\hline За видами & & \multicolumn{2}{|c|}{ За галузями/об'єднаннями } \\
\hline \multicolumn{4}{|c|}{ Програмно-аналітичне супроводження єдиної бази } \\
\hline \multicolumn{4}{|c|}{$\widehat{\longleftrightarrow}$} \\
\hline \multicolumn{4}{|c|}{ Організаційно-методичне забезпечення } \\
\hline \multirow{2}{*}{\multicolumn{2}{|c|}{$\begin{array}{ll}\text { - } & \text { Мінфін } \\
\text { - } & \text { Держстат } \\
\text { - } & \text { ДФС } \\
\text { - } & \text { Держтеокадастр } \\
\end{array}$}} & \multicolumn{2}{|c|}{$\begin{array}{ll}\text { - } & \text { МінАПП, обласні й районні ДА } \\
\text { • } & \text { Місцеві громади } \\
\text { - } & \text { Аудитові і експерті установи } \\
\text { Аугапалата України }\end{array}$} \\
\hline & & иль регуляторі & \\
\hline \multicolumn{4}{|c|}{ 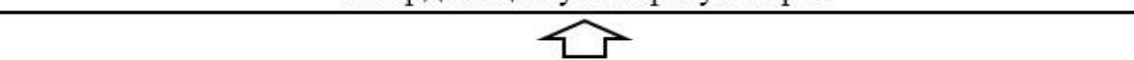 } \\
\hline \multicolumn{4}{|c|}{ Методологія звітності } \\
\hline $\begin{array}{l}\text { Стратегія } \\
\text { статистики } \\
\text { ООО } \\
\text { ФОА }\end{array}$ & $\begin{array}{c}\text { Директиви } € \mathrm{C}, \\
\text { IRC, } \\
\text { MCФ3 } \\
\ldots\end{array}$ & $\begin{array}{r}\text { Урядові } \\
\text { стратегії, } \\
\text { програми } \\
\text { розвитку }\end{array}$ & $\begin{array}{c}\text { Наукове } \\
\text { забезпечення в } \\
\text { т.ч. } 3 \text { досвіду } \\
\text { УРСР }\end{array}$ \\
\hline \multicolumn{4}{|c|}{ Напрями } \\
\hline \multicolumn{4}{|c|}{$\widehat{\longleftarrow}$} \\
\hline \multicolumn{4}{|c|}{ Кількісне і якісне зростання стейкхолдерів } \\
\hline
\end{tabular}

Рис. 3. Концептуальні положення розбудови системи обліково-інформаційного забезпечення управління 
Зростання попиту на обліково-звітну інформацію можливо задовольнити лише розбудовою комплексної системи її продукування, обробки та аналітичного узагальнення. Першочерговим на цьому шляху є розуміння концептуальних положень цієї роботи. В концептуальному сенсі ця робота базується на:

- формуванні й постійному вдосконаленні методології нової звітності (напрями визначаються стратегією як статистики $\mathrm{OOH}$, ФАО, директив $\mathrm{EC}$, IRC, так і вітчизняними науковими напрацюваннями);

- координації нормативно-правової та організаційно-методичної роботи відповідальних інституцій регуляторів (від Держстату, Мінфіну до наукових і експертних установ);

- формуванні цілісної інформаційної бази, яка складається і поділяється за сегментами: за видами - фінансова, статистична, адміністративна, місцева; за відомствах/регуляторах Держстату, ДФС, ОДА і т.п.; по регіонах - по Україні, області, району, об’єднаній територіальній громаді; за галузями і об'єднаннями виробників - фермери, олійно-жирова галузь тощо.

Очевидно, що інформаційні технології дозволяють досягти максимального узагальнення всіх сегментів обліково-звітної інформації у єдиній - загальнодержавній базі та мати доступ до іiі розгляду у будь-якому розрізі (галузевому, територіальному тощо).

Сучасні вимоги до оприлюднення інтегрованої звітності лише не власному веб-сайті підприємства не можуть задовольнити ні їх самих, ні місцеві органи, ні галузеві відомства. Це важливо для програм розвитку території, регіону, держави. Відтак, назрілою $є$ постанова завдання на формування загальнодержавної інформаційної інституції. В інформаційну епоху розвитку це не тільки усвідомлення, а й практика усіх розвинутих країн. А для України, управління якої перебуває в інформаційному хаосі, це першочергове завдання.

Не менш складною, як і не менш важливою, є робота з формування професійних навичок та відповідальності бухгалтерів підприємств.

Наші попередні дослідження переконливо засвідчують, що саме бухгалтерські служби і натепер, i у майбутньому $\epsilon$ найбільш функціонально спроможними забезпечувати якісну інтегровану звітність [6]. До того ж в Україні функціонують та динамічно розвиваються інститут професійних аудиторів (САУ, АПУ) та професійні громадські об'єднання бухгалтерів (ФАБФ, ФПБАУ, УАСБА), які спроможні активізувати роботу; розбудови нової інформаційної системи управління.

Відомо, що натепер аудиторські компанії України націлені не тільки на перевірку інтегрованої звітності, але і на іiі спільне формування 3 підприємствами. Їх робота каталізує бухгалтерську (поведінкову) відповідальність, змінюе відношення до звітності власників та керівників підприємств. В Україні зростають аутсорсингові бухгалтерські послуги і аудиторські компанії стають не просто генераторами звітності, а прикладом складання найкращої інтегрованої звітності по своїх клієнтах.

Висновки і пропозиції. В інформаційну епоху розвитку, функціонування дієвої звітнооблікової системи $\epsilon$ першою умовою ефективності управління на усіх рівнях. Однією з причин слабкого, безсистемного розвитку економіки України, «надуманості» заходів у програмах і стратегіях подолання кризи, є відсутність в країні цілісної й комплексної системи звітності. Управління в Україні перебуває натепер в інформаційному хаосі.

У своїй історії Україна формувала дієві системи інформаційного забезпечення управління. Ми маємо, як радянський досвід, так і спроби побудови нової системи звітності в аграрному секторі економіки у період 2000 - 2010 рр. Цей досвід стає важливим тепер, коли Україна у світовому тренді намагається запровадити інтегровану звітність та розбудувати статистику сільського господарства за методологією ООН і ФАО.

Об’єктивним чинником відродження системи звітності в Україні $є$ і процеси децентралізації та зростання відповідних запитів до підприємництва. Сприяє цьому і вітчизняний ринок аутсорсингових бухгалтерських послуг, що мінімізує проблеми довільного розкриття інформації нефінансового характеру.

Вітчизняна бухгалтерська наука спроможна змоделювати та концептуально, методологічно й методично забезпечити розбудову в Україні сучасної обліково-інформаційної системи. Комплексність цієї роботи зорганізовується на принципах: запити - можливості; світові тренди національні інтереси; біхевіористична основа - надможливості * IT; регуляторні чинники підприємницька ініціатива тощо. 


\section{Список використаних джерел}

http://efm.vsau.org/

1. Гуцаленко Л.В., Довгаль Е.О. Обліково-інформаційна система забезпечення управління сільськогосподарським підприємством. Економіка. Фінанси. Менеджмент: актуальні питання науки і практики. 2016. № 8. С. 82-92.

2. Правдюк Н.Л. Звітність спільної діяльності без створення юридичної особи: організаційно-методичні положення. Проблеми теорії та методології бухгалтерського обліку, контролю і аналізу. Сер.: Бухгалтерський облік, контроль і аналіз. 2014. Вип. 2. С. 228-237.

3. Здирко Н.Г. Удосконалення фінансової звітності фермерських господарств в частині державної підтримки. Облік і фінанси. 2013. № 2(60). С. 16-24.

4. Безверхий К.В. Методичні засади формування інтегрованої звітності підприємства. Облік і фінанси. 2014. № 3(65). С. 8-14.

5. Легенчук С.Ф., Батіщева Н.М. Фінансова звітність футбольного клубу: галузеві особливості представлення фінансової інформації. Вісник Житомирського державного технологічного університету. Сер.: Економічні науки. 2013. № 2. С. 110-117.

6. Жук В.М. Інтегрована звітність: ретроспектива і перспектива в Україні. Облік і фінанси. 2019. № 1(83). C. 20-27.

7. Сокіл О.Г. Обліково-аналітичне забезпечення сталого розвитку аграрного підприємництва: теорія, методологія, практика: автореф. дис. на здобуття наук. ступеня д.е.н.: спец. 08.00.09 - бухгалтерський облік, аналіз та аудит. ННЦ «IAE», 2019, 38 с.

8. Концепція відомчої аграрної статистики в аграрному секторі економіки України / Звіт про науково-дослідну роботу «Розробити науково-методологічні засади обліково-аудиторського забезпечення конкурентоспроможного аграрного виробництва» (заключний). К.: ННЦ «IAE», 2015. 484 с.

9. Методичні рекомендації із облікового забезпечення відомчої (аграрної) статистики в тестових підприємствах / Звіт про науково-дослідну роботу «Науково-методологічні засади розвитку обліку, звітності та аудиту в умовах глобалізації» (заключний). К.: ННЦ «ІАЕ», 2010. 354 с.

10.Про бухгалтерський облік та фінансову звітність в Україні: Закон України від 16.07.1999 p. № 996-XIV. URL: https://zakon.rada.gov.ua/laws/show/996-14

11.Глобальная стратегия совершенствования сельскохозяйственной и сельской статистики. URL: http://www.fao.org/docrep/016/am082r/am082r.pdf

12.Методичні рекомендації із складання «Звіту про управління»: затверджено Наказом Міністерства фінансів України від 07.12.2018 р. № 982. URL: https://zakon.rada.gov.ua/ rada/show/v0982201-18

\section{References}

1. Hutsalenko, L.V. \& Dovhal, E.O. (2016). Oblikovo-informatsiina systema zabezpechennia upravlinnia silskohospodarskym pidpryiemstvom [Accounting and information system providing management of agricultural enterprises]. Ekonomika. Finansy. Menedzhment: aktualni pytannia nauky $i$ praktyky, (8), 82-92 (in Ukraine).

2. Pravdiuk, N.L. (2014). Zvitnist spilnoi diialnosti bez stvorennia yurydychnoi osoby: orhanizatsiino-metodychni polozhennia [Reporting of joint activity without establishing a legal entity: organizational and methodical provisions]. Problemy teorii ta metodolohii bukhhalterskoho obliku, kontroliu i analizu. Ser.: Bukhhalterskyi oblik, kontrol i analiz, (2), 228-237 (in Ukraine).

3. Zdyrko, N.H. (2013). Udoskonalennia finansovoi zvitnosti fermerskykh hospodarstv v chastyni derzhavnoi pidtrymky [Improvement of farm enterprises financial statements regarding state support]. Oblik i finansy, 2(60), 16-24 (in Ukraine).

4. Bezverkhyi, K.V. (2014). Metodychni zasady formuvannia intehrovanoi zvitnosti pidpryiemstva [Methodological bases of creating the enterprise's integrated reporting]. Oblik i finansy, 3(65), 8-14 (in Ukr.).

5. Lehenchuk, S.F. \& Batishcheva, N.M. (2013). Finansova zvitnist futbolnoho klubu: haluzevi osoblyvosti predstavlennia finansovoi informatsii [Financial reporting of the football club: Sectoral peculiarities of presentation of financial information]. Visnyk Zhytomyrskoho derzhavnoho tekhnolohichnoho universytetu. Ser.: Ekonomichni nauky, (2), 110-117 (in Ukraine).

6. Zhuk, V.M. (2019). Intehrovana zvitnist: retrospektyva i perspektyva v Ukraini [Integrated reporting: A retrospective and perspective in Ukraine]. Oblik i finansy, 1(83), $20-27$ (in Ukraine).

7. Sokil, O.H. (2019). Oblikovo-analitychne zabezpechennia staloho rozvytku ahrarnoho pidpryiemnytstva: teoriia, metodolohiia, praktyka [Accounting and analytical support for the sustainable development of agrarian entrepreneurship: theory, methodology, practice] (Dissertation abstract). Kyiv: NNTs «IAE» (in Ukraine). 
http://efm.vsau.org/

8. Kontseptsiia vidomchoi ahrarnoi statystyky $\mathrm{v}$ ahrarnomu sektori ekonomiky Ukrainy [Concept of departmental agrarian statistics in the agrarian sector of the Ukrainian economy] (2015). In Zvit pro naukovodoslidnu robotu «Rozrobyty naukovo-metodolohichni zasady oblikovo-audytorskoho zabezpechennia konkurentospromozhnoho ahrarnoho vyrobnytstva» (zakliuchnyi). Kyiv: NNTs «IAE» (in Ukraine).

9. Metodychni rekomendatsii iz oblikovoho zabezpechennia vidomchoi (ahrarnoi) statystyky v testovykh pidpryiemstvakh [Methodical recommendations on accounting support of departmental (agrarian) statistics in test enterprises] (2010). In Zvit pro naukovo-doslidnu robotu "Naukovometodolohichni zasady rozvytku obliku, zvitnosti ta audytu v umovakh hlobalizatsii» (zakliuchnyi). Kyiv: NNTs «IAE» (in Ukraine).

10. Verkhovna Rada Ukrainy. (16.07.1999). Pro bukhhalterskyi oblik ta finansovu zvitnist v Ukraini: Zakon Ukrainy [On Accounting and Financial Reporting in Ukraine: The Law of Ukraine]. Retrieved from https://zakon.rada.gov.ua/laws/show/996-14 (in Ukraine).

11.Hlobalnaia stratehyia sovershenstvovanyia selskokhoziaistvennoi y selskoi statystyky [Global strategy for the improvement of agricultural and rural statistics]. (2012). Retrieved from http://www.fao.org/docrep/016/am082r/am082r.pdf (in Russiya).

12.Ministerstvo finansiv Ukrainy. (07.12.2018). Metodychni rekomendatsii iz skladannia «Zvitu pro upravlinnia» [Methodical recommendations for drawing up the «Management Report»]. Retrieved from https://zakon.rada.gov.ua/rada/show/v0982201-18 (in Ukraine).

\section{Відомості про авторів}

ЖУК Валерій Миколайович - доктор економічних наук, професор, академік НААН,головний науковий співробітник,Національний науковий центр «Інститут аграрної економіки», м. Київ, Україна.

МЕЛЬНИК Катерина Петрівна- кандидат економічних наук, доцент, Східноєвропейський університет імені Лесі Українки, м. Луцьк, Україна.

ZHUK Valeryi- Doctor of Economics, Professor, Academician of NAAS, Chief Scientific Officer, National Research Center "Institute of Agrarian Economy", Kyiv, Ukraine

MELNYK Kateryna - Candidate of Science (Economics), Associate Professor, Lesya Ukrainka Eastern European University, Lutsk, Ukraine.

ЖУК Валерий Николаевич- доктор экономических наук, профессор, академик НААН, главный научный сотрудник, Национальный научный центр «Институт аграрной экономики», г. Киев, Украина.

МЕЛЬНИК Екатерина Петровна - кандидат экономических наук, доцент, Восточноевропейский университет имени Леси Украинский., Г. Луцьк, Украина.

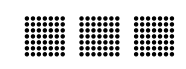

УАК 657.336.764.1

\begin{tabular}{l|r} 
ОБЛІКОВЕ ЗАБЕЗПЕЧЕННЯ УПРАВЛІННЯ \\
ФІНАНСОВИМИ АКТИВАМИ \\
ПІДПРИЕМСТВА
\end{tabular}

Однією із ключових категорій фінансового світу є фінансовий актив. Різним сегментам фінансового ринку (кредитному, фондовому, валютному, ринку фінансових послуг) притаманні різні категорії фінансових активів, обіг яких опосередковує рух коштів як всередині краӥни, так $i$ за ї̈ межами. За участю фінансових активів відбувається ефективне переміщення фінансових ресурсів у національних чи міжнародних масштабах. Як правило, отримання фінансових активів чи контролю над ними, визначає мотивацію учасників фінансових чи комериійних операцій.

(๑) о.О. ЛЮБАР, 2019 